\title{
The Possibility of COVID-19 Pandemic in Eliminating Burning Activities: A Case Study at Ogan Komering Ilir Regency, South Sumatera
}

\author{
Lailan Syaufina $^{1^{*}}$, Muhammad Hudzaifah Rihuljihad ${ }^{1}$, Ati Dwi Nurhayati ${ }^{1}$ \\ ${ }^{1}$ Department of Silviculture, Faculty of Forestry and Environment, IPB University, Academic Ring Road Campus IPB \\ Dramaga, Bogor, Indonesia 16680
}

Received Februari 18, 2021/Accepted November 2, 2021

\begin{abstract}
Forest and land fires occur almost every year in South Sumatera Province, including at Ogan Komering Ilir (OKI) Regency, mainly due to uncontrolled burning activities. This region has the largest peatland responsible for the adverse haze impacts. The advent of the coronavirus (COVID-19) pandemic in early 2020 has triggered massive consequences across the global communities, including Indonesia. Therefore, large-scale regulations on social restrictions were enacted. The purpose of this study is to analyze the variations in hotspots as forest and land fire indicators before and during the COVID-19 pandemic in OKI as well as to determine the rainfall effects. Daily Terra/Aqua MODIS satellite feeds and rainfall data between January 2018 and December 2020 served as the research materials. Subsequently, the paired t-test and correlation assessment were used to examine the hotspot variations in both datasets, respectively. The results showed significant statistical differences before and during the pandemic. Consequently, social restrictions were assumed to instigate the decline in burning activities. Furthermore, the rainfall demonstrated a vulnerable correlation to the hotspots, indicating that human factor was more pronounced as a fire trigger.
\end{abstract}

Keywords: haze, fire detection, Indonesia, burning activities

*Correspondence author, email:lailans@apps.ipb.ac.id, tel. +62-251-8626806,fax. +62-251-8626886

\section{Introduction}

Forest and land fires are common occurrences in South Sumatera Province. This region is among the fire-prone locations in Indonesia (KLHK, 2018) with the highest hotspots and burned area (Ardiansyah et al., 2017) and widespread forest fire regions (Indratmoko \& Rizqihandari, 2019), covering 336,798 ha of burned area in 2019 (KLHK, 2021). Based on Terra/AQUA MODIS satellite data, the greatest hotspot is situated in Ogan Komering Ilir (OKI) Regency, also known as the most affected zone (Indratmoko \& Rizqihandari, 2019), with peak periods in dry seasons, particularly between August and September. However, the fires are known to have instigated haze alongside a significant impact on public health and are strongly related to the peatland incidence where huge carbon materials are released during the burning. These substances combine with water vapor producing thick smoke haze containing aerosols, particulate matter, and other trace gases which are hazardous to human health and the surrounding environments (Fujii et al., 2014; Heriyanto et al., 2015; Jayarathne et al., 2018; Kiely et al,. 2019; 2020).

South Sumatera encompasses a peatland area of approximately 1.2 million ha or $14.5 \%$ of the total region. The province is a vital natural resource with potentials for community livelihood. Among the peatland area distribution, OKI demonstrated the maximum coverage of approximately 640,647 ha (50\%) (BBSDLP, 2011).
Currently, certain segments appear degraded, unproductive, and unsustainably managed with limitation to agriculture applications (Rosanti, 2014). However, the burnt peatland recorded severe impacts, compared to non-peatlands. The fires are triggered by land drying during land preparation and other uses as peat is a good fuel with irreversible drying characteristics (Usup, et al., 2004). Also, the peat dryness is expressed by the moisture content, due to rainfall effects (Putra, 2011). Furthermore, most of the burnt areas were outside the concession, while internal session showed particular typologies, including the fire activities in HTI (industrial forest plantation) on non-forested (26\%) and forested land $(24 \%)$, as well as in oil palm on non-forested (17\%) and forested land (2\%) (Ardiansyah et al. 2017).

Forest and land fires are monitored and detected using hotspot numbers and satellite data distributions. Previous studies show that hotspot data are employed as the key indicator of fire occurrence (Nurdiana \& Risdiyanto, 2015; Usman et al., 2015), particularly clustered and sequential hotspots (Kirana et al., 2015; Wijaya et al., 2016; Syaufina \& Sitanggang, 2018). The Ministry of Forestry and Environment based on the provisions of Number P.8/MENLHK/SETJEN/KUM.1/3/2018, defines a hotspot as a location with the temperature above a certain threshold from remote sensing data, used as a forest and land fire indicator.

Generally, fire occurrences in Indonesia are caused by 
human factors both intentionally and unintentionally (Dennis et al., 2005; Syaufina, 2018). The intention is common for land preparation purposes, particularly in the approved cultivation areas (HGU). Fire in peatlands is mainly caused by burning activities (Pasaribu \& Friyatno, 2012; Syaufina, 2018). The abandoned farmland typically has a $2-3 \mathrm{~m}$ peat depth and is located in the downstream watershed (Pasaribu \& Friyatno, 2012). Human activity plays a very important role in causing a number close to $100 \%$ of forest and peatland fires. Apart from intentionally burning, climate change was also suspected as a significant wildfire source, with several indicators including increasing temperature, decreasing humidity, and low precipitation (Afifuddin et al., 2019).

Indonesia was first hit by the coronavirus (COVID-19) pandemic in early 2020 . The RNA virus possesses a particle size range of $120160 \mathrm{~nm}$. This disease mainly infects animals, including bats and camels (Riedel et al., 2019). Consequently, the World Health Organization announced COVID-19 as a global pandemic on March 12, 2020, and in subsequent weeks, precisely on March 29, the confirmed cases had attained 634,835, with 33,106 deaths recorded worldwide. Meanwhile in Indonesia, 1,528 positive cases and 136 deaths were reported. Therefore, to minimize the rapid spread, the Indonesian government issued a regulation (Number 21) on large-scale social restriction (PSBB) in 2020 (Nurhalimah, 2020).

This study aims to determine the possibility of social restrictions in the burning prevention in OKI. These activities are approached by hotspot variations as indicators of forest and land fires before and during the COVID-19 outbreak. In addition, the PSBB enactment is assumed to decrease the triggers of forest and land fire. However, studies on the relationship between the COVID-19 pandemic and the fire appear very limited. Therefore, the purpose of this research is to analyze the hotspot differences prior and during the COVID-19 pandemic, in addition to determining the rainfall influence.

The present study is expected to provide valuable information on burning activities at the research area, before and during the COVID-19 pandemic, with potential usefulness as a reference for forest and land fire control in the selected region.

\begin{abstract}
Methods
Study area Figure 1 shows the position of OKI between the ranges of latitudes $\mathrm{S} 2^{\circ} 30^{\prime}-\mathrm{S} 4^{\circ} 15^{\prime}$ and longitudes $\mathrm{E} 104^{\circ} 20^{\prime}-\mathrm{E} 106^{\circ} 00^{\prime}$. This location is among the regencies in South Sumatera Province, Indonesia, with an average elevation of $10 \mathrm{~m}$ asl. The name originated from two main rivers in the region: Ogan and Komering, with relative influence on the dominant swamps. Furthermore, the regency is also located in both floodplains covering a total area of $19,023.47 \mathrm{~km}^{2}$, where $7,690 \mathrm{~km}^{2}(40.42 \%)$ forms the peatland area prone to the fire source.

OKI comprises 18 districts, including Air Sugihan, Cengal, Jejawi, Kayu Agung (City), Lempuing, Lempuing Jaya, Mesuji, Mesuji Raya, Mesuji Makmur, Pampangan, Pangkalan Lapan, Pedamaran, Pedamaran Timur, Sirah Pulau Padang, Sungai Menang, Tanjung Lubuk, Teluk Gelam, and Tulung Selapan. The climate of OKI Regency is classified as wet tropical with annual rainfall $>2,500 \mathrm{~mm} \mathrm{year}^{-1}$ and average rainy days of 116 year $^{-1}$. Furthermore, the dry season predominantly occurs between May and October, but the rainy period appears from November-April. The OKI population is estimated at 731,721 persons or with a population density of approximately 39 persons $\mathrm{km}^{-2}$. Major cultivated crops include coffee, sugar cane, oil palm, rubber, cocoa bean, pineapple, tea, and fish. Furthermore, burning is one of the cultures in land preparation during farming and fishing activities.
\end{abstract}

Materials The research materials incorporated daily Terra/AQUA MODIS satellite hotspot data of OKI from January 2018-December 2020 and were also downloaded from the official website of the Centre for Remote Sensing Utilization, National Institute of Aeronautics and Space/LAPAN (http://modis-catalog.lapan.go.id). In

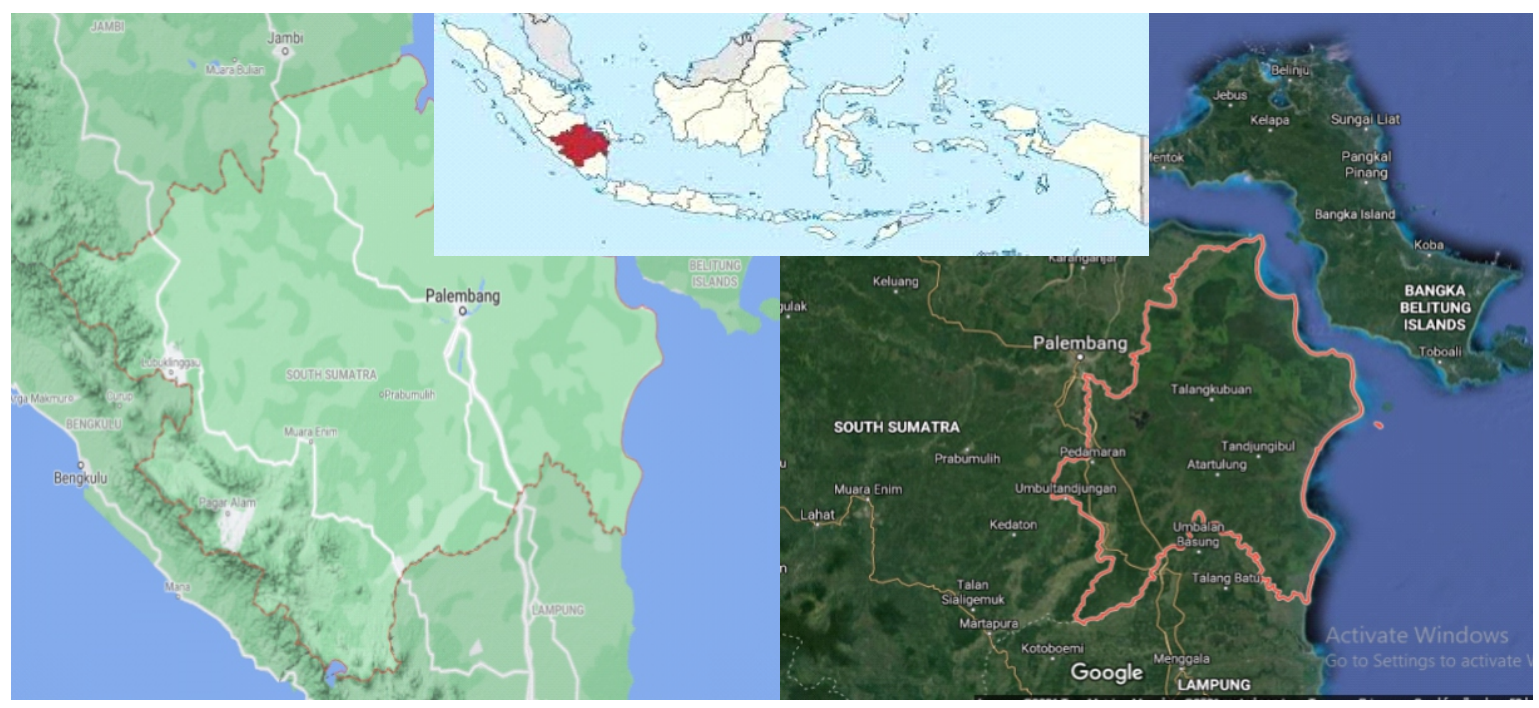

Figure 1 Study area of Ogan Komering Ilir Regency, South Sumatera Province, Indonesia. 
addition, daily rainfall data for similar intervals were obtainable from the National Agency of Meteorology, Climatology and Geophysics (BMKG), as well as the general map from the Google My Maps application. Furthermore, the JASP 0.14.1.0 software was employed for statistical analyses involving descriptive, t-test, and correlation test of hotspot and rainfall data.

Daily hotspot and rainfall data of OKI between January 2018 and December 2020 were downloaded from LAPAN and BMKG, respectively. The classification of the hotspot data was based on monthly distribution per year and on district distribution to define the fire season and the most prone district. Meanwhile, the daily rainfall distributions were used to determine the mean rainfall value for the threeyear duration and to evaluate the rainfall-hotspot correlation. Finally, hotspot data for the period under review were analyzed, using the Google My Maps application to generate a spatial hotspot distribution during and before the COVID19 pandemic (Figure 2).

Data analyses The hotspot differences before COVID-19 (2018 and 2019) and the actual arrival (2020) were analyzed. Paired t-test was employed to successively compare the hotspots between 2018 and 2019, 2019 and 2020, as well as 2018 and 2020. Similar assessment and comparison were also applied to evaluate the rainfall. In addition, the correlation test was deployed to determine the relationship between both variables and to observe the extent of rainfall influence on the fire occurrence. The correlation equation is as shown in Equation [1].

$r_{\mathrm{xy}}=\frac{\mathrm{n} \Sigma \mathrm{xiyi}-\left(\sum \mathrm{xi}\right)(\Sigma \mathrm{yi})}{\sqrt{\left\{\mathrm{n} \Sigma \mathrm{xi}^{2}-(\Sigma \mathrm{xi})^{2}\right\}} \sqrt{\left.\{\mathrm{n} \Sigma \mathrm{yi})^{2}-(\Sigma \mathrm{yi})^{2}\right\}}}$ note: $r_{x y}=$ correlation coefficient of linearity, $x=$ rainfall data variable, $y=$ hotspot data variable, and $n=$ number of data. The $r_{x y}$ correlation coefficient value ranges from -1 to 1 . A positive symbol indicates a proportional relationship, while a negative one shows an inverse proportionality.

\section{Results and Discussion}

Hotspot distribution before and during the COVID-19 pandemic Fire and haze are common phenomena in OKI, with great influence on human health, economic activities, and the surrounding environment. The impacts are not only limited to the natives but further extend to neighboring provinces and countries. This study analyzed the hotspot data as forest and land fire indicators before $(2018,2019)$ and during COVID-19 (2020). Hotspot distribution varies in the three periods under review, where the maximum and minimum occurrences were recorded in $2019(13,871)$ and 2020 (435), respectively. Descriptive analyses showed that the daily hotspots in 2018,2019 , and 2020 ranged from $0-77$, $1-1,398$, and 1-26, correspondingly, as represented in Table 1 .

The temporal distribution shows that hotspots were discovered between January and December, although the fire season started in January and peaked in October 2018. However, the incidence commenced slightly late in 2019 , as a large hotspot number was reported in July, with the maximum point attained in October. Based on Figure 3, no hotspot was recorded in June 2019. The extreme dry season in 2019 possibly triggered the large fire incidence as indicated by extensive hotspots, corresponding to El Nino southern oscillation and Indian Ocean dipole (Hendrawan et al., 2019; Novitasari et al., 2019). Similar conditions have been

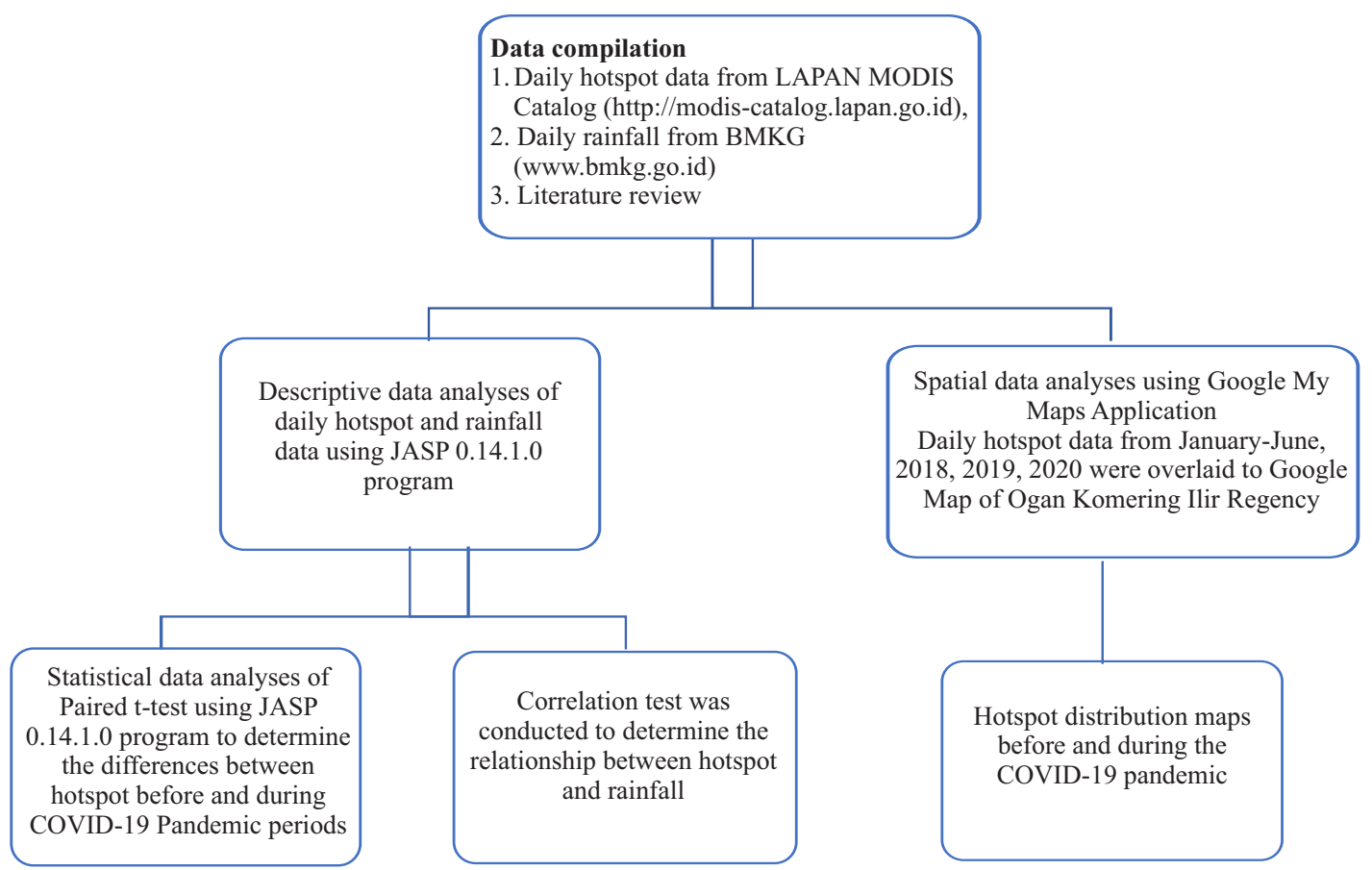

Figure 2 Flow chart of study implementation. 
Table 1 Descriptive statistics of daily hotspot distribution at OKI Regency in 2018, 2019, and 2020

\begin{tabular}{lrrr}
\hline & Hotspot 2018 & Hotspot 2019 & Hotspot 2020 \\
\hline Valid & 183 & 166 & 130 \\
Missing & 913 & 930 & 966 \\
Mean & 5.213 & 83.560 & 3.346 \\
Std. deviation & 8.613 & 183.317 & 3.617 \\
Minimum & 0.0 & 1.0 & 1.0 \\
Maximum & 77.0 & 1398.0 & 26.0
\end{tabular}
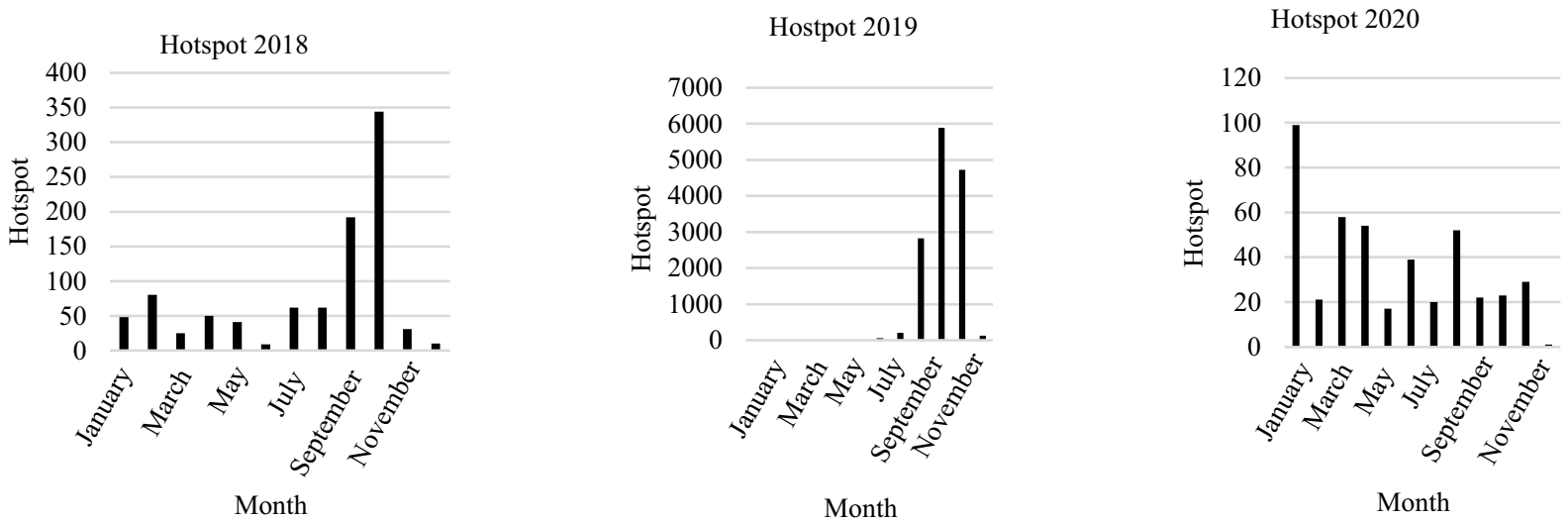

Figure 3 Monthly hotspot distribution at OKI Regency from 2018-2020.

experienced in 1998 and 2015 (Asteriniah \& Sutina, 2017). During the introduction of social restrictions in 2020, the hotspot numbers, however, decreased by 54.4 and $96.9 \%$ of the overall estimations in 2018 and 2019. Figure 4 shows a minimal temporal distribution for 2020, compared to 2018 and 2019. Furthermore, it was assumed that the pandemic instigated a significant constraint in human activities, resulting to a decline in burning. This observation is in line with the statistical data analysis (Table 2), where a substantial variation was visible between 2018 and 2020 as well as 2019 and 2020 hotspots, indicating significant decreasing figures for both compared intervals. Apparently, burning activities were known to reduce drastically, mainly as a result of the social restrictions.

The Indonesian government issued a regulation on largescale social restriction (PSBB) to curb the COVID-19 spread. This health quarantine measure is defined as a "restriction on certain human activities in selected locations possibly infected or contaminated by the virus" (UU 6/2018, Chapter 1 number 11). Also, PSBB is among the health isolation categories, apart from houses, hospitals, and quarantine areas (UU 6/2018, Chapter 49 verse (1)). The objective of the initiative is primarily to prevent the broader spread of public health emergency disease (KKM) among population in a certain area (UU 6/2018, Chapter 59 verse (2)). In addition, the restricted activities including no activities for schools and workplaces, religious programs, and/or public facilities (PP 21/2020, Chapter 4 verse (1)). Furthermore, PSBB was implemented by provincial and regency/city governments, after the approval of the Ministry of Health through the Ministerial decrees (PP 21/2020, Chapter 2 verse (1) and UU 6/2018, Chapter 49 verse (3).
Figure 5 represents the spatial hotspot distribution in OKI from 2018-2020. The results of data mapping were achieved using Google My Map. Consequently, clusters were formed covering the research location as a strong indicator for the actual fire (Kirana et al., 2015; Wijaya et al., 2016; Syaufina \& Sitanggang, 2018).

Figure 6 shows the fire distribution virtually in every district of OKI before and during the COVID-19 crisis. The highest average hotspot (52) occurred in Tulung Selapan, between January and June, followed by Pedamaran (38), Pampangan (38) and Cengal (37). This outcome observed Tulung Selapan as the most fire-prone district in OKI (Meiriza et al., 2017; Nainggolan et al., 2020). However, Air Sugihan, Cengal, Bayung Lencir were on a medium scale, while the rest were reportedly low (Meiriza et al., 2017). Furthermore, fire-related human activities appear as the primary cause of forest and land fires in this region, including the 'sonor' techniques employed in rice planting, where the seeds are spread on the burned area (Zulfah et al., 2020), and land preparation for plantation and fishing (Nurhayati et al., 2020).

Moreover, the pandemic era showed additional numbers of hotspot distribution districts (10) compared to the other two periods of 2018 (7) and 2019 (3). Also, it appears that burning activities are currently implemented during COVID19. However, the OKI had attempted to adapt zero burnings by responding with the prohibition on the use of fire in land clearing, despite it has not been fully implemented (Waluyo et al., 2020).

The effects of rainfall on hotspot In tropical regions, rainfall forms an important climatic consideration that 

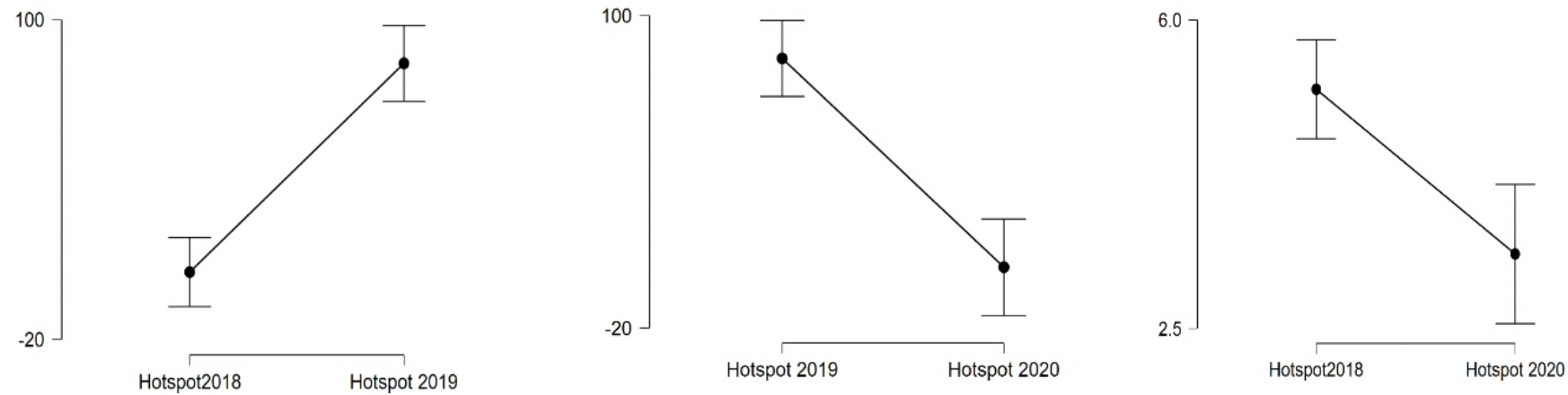

Figure 4 Hotspot distribution comparison at Ogan Komering Ilir District before (2018-2019 and during the COVID-19 pandemic (2020).

Table 2 Paired sample test of hotspot in 2018,2019, and 2020

\begin{tabular}{ccrrr}
\hline Measure 1 & Measure 2 & \multicolumn{1}{c}{$\mathrm{t}$} & $\mathrm{df}$ & \multicolumn{1}{c}{-value } \\
\hline Hotspot 2018 & Hotspot 2019 & -4.262 & 94 & $<0.001$ \\
Hotspot 2019 & Hotspot 2020 & 3.273 & 63 & 0.002 \\
Hotspot 2018 & Hotspot 2020 & 2.224 & 69 & 0.029 \\
\hline
\end{tabular}

Note: Student's t-test.

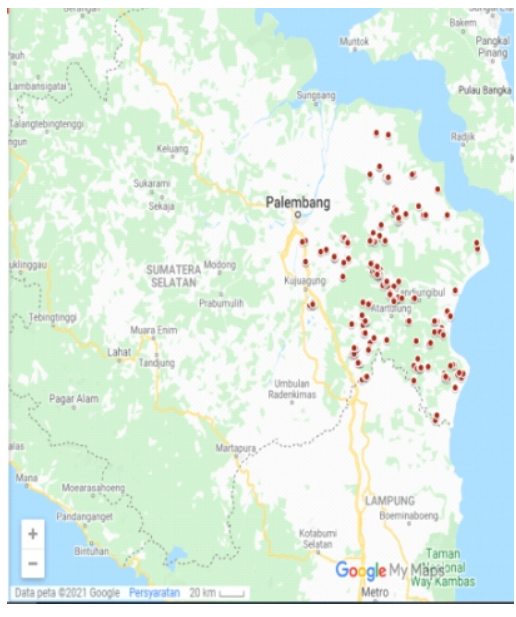

2018

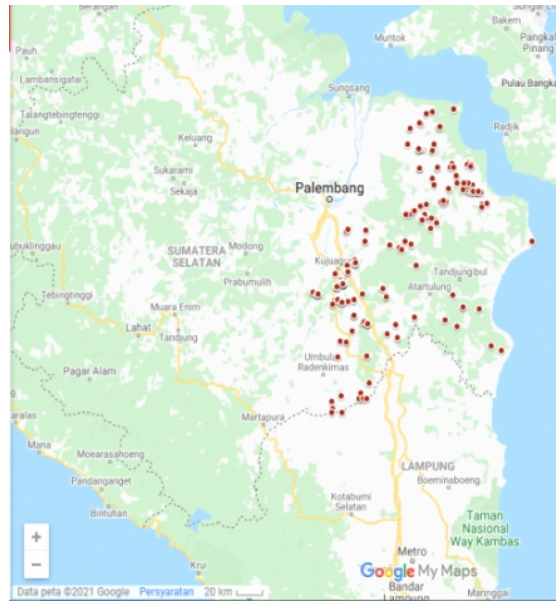

2019

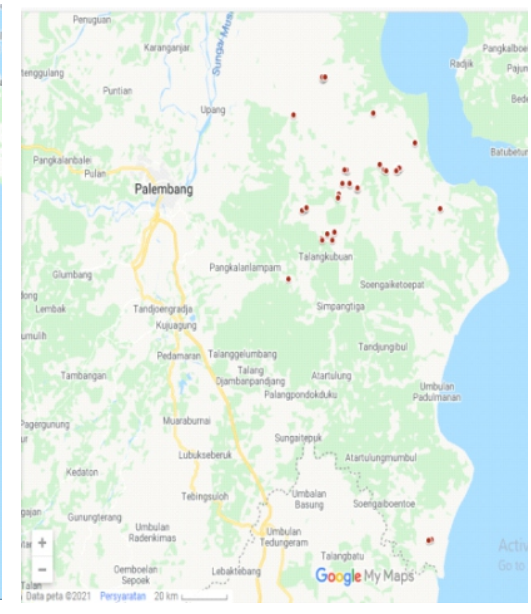

2020

Figure 5 Spatial hotspot distribution at Ogan Komering Ilir Regency from 2018-2020.

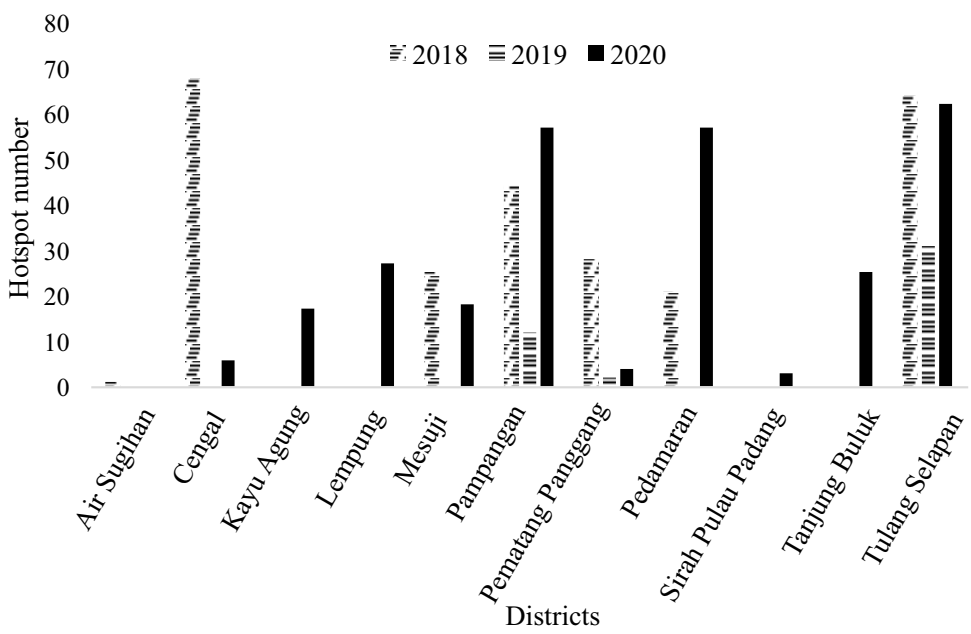

Figure 6 Hotspot distribution at Districts of Ogan Komering Ilir Regency from January-June 2018, 2019, 2020. 
mostly influences forest and land fires and also determines the quantity and quality of forest fuels (Syaufina, 2008). Indonesia shows a wide rainfall variation, based on regions and the individual effect on the fire seasons. This weather element has the potential to serve as a parameter for fire risk prediction in a particular duration. In peatlands, the seasons show a huge impact on fuel moisture, bulk density, and water level (Syaufina et al., 2004).

There were fluctuations in rainfall distributions from 2018-2020. Table 3 shows the statistical analyses of the minimum mean daily occurrence in $2019(7.1 \mathrm{~mm})$ and the maximum in $2020(10.6 \mathrm{~mm})$. In addition, significant variations were reported from 2018-2019 and 2019-2020, with no change between 2018 and 2020 (Table 4). Furthermore, the OKI Regency in A region, obtained a single peak in both the rainy and dry seasons (July-August) (Aldrian \& Susanto, 2003).

The dry season is determined by minimal monthly rainfall that influences fire occurrences and hotspot number as potential indicators (Syaufina, 2008). The hotspot number is increased as the location becomes drier. Also, the rainfall significantly decreased from 20182019, where El Nino occurred in the region. Therefore, forest and land fires were known to peak in 2019 (Figure 3), particularly from September, October to November, known as the common periods for most hotspots (Meiriza et al., 2017). One of the primary triggers of forest and land fires is lesser rainfall and extreme anomalies (Nurdiati et al., 2019), with the potentials to decrease peat moisture content and increase fire risk

Table 3 Descriptive statistics of daily rainfall distribution at OKI Regency in 2018, 2019, and 2020

\begin{tabular}{lccc}
\hline & Rainfall 2018 & Rainfall 2019 & Rainfall 2020 \\
\hline Valid & 262 & 286 & 242 \\
Missing & 834 & 810 & 854 \\
Mean & 9.664 & 7.103 & 10.561 \\
Std. deviation & 16.553 & 14.364 & 16.859 \\
Minimum & 0.0 & 0.0 & 0.0 \\
Maximum & 97.0 & 80.5 & 90.6 \\
\hline
\end{tabular}

(Armanto et al., 2018). This was followed by a significant rainfall improvement from 2019-2020, as illustrated in Figure 7.

Figure 8 represents the statistical analysis of a very inefficient correlation $(\mathrm{r}=0.103)$ between daily hotspots and rainfall. This means that natural factors demonstrated a more vulnerable influence on burning activities, compared to human elements. A negative sign depicts the tendency for the hotspot to decline due to the increasing rainfall. Similar studies also reported a weak correlation $(\mathrm{r}=0.307)$ between the hotspots and rainfalls in Sumatera and Kalimantan (Prayoga \& Yananto, 2017). This outcome indicates that both variables do not linearly correlate as rainfall is not a single influencing factor of forest and land fires (Prasasti et al., 2012; Sitanggang et al., 2018). The alteration of climate parameters shows the slight climate change present in southern Sumatera, particularly in OKI, but without any effect on land and forest fire occurrences (Afifuddin et al., 2019). Furthermore, the fire incidence in the study region is strongly influenced primarily by human activities. Economic variables, including the proportion of plantation landholdings and the reported use of fires for agricultural land clearing, were important in comprehending the fire count at the regency level, although rainfall, slope, and population density, have been the most important considerations in predicting fires (Sze et al., 2019). Therefore, it appears OKI forest and land fires are sufficiently influenced by human activities, compared to the natural factors, including the rainfalls.
Table 4 Paired sample test of rainfall in 2018, 2019, and 2020

\begin{tabular}{ccccc}
\hline Measure 1 & Measure 2 & $\mathrm{t}$ & $\mathrm{df}$ & $p$-value \\
\hline Rainfall 2018 & Rainfall 2019 & 1.420 & 204 & 0.157 \\
Rainfall 2019 & Rainfall 2020 & -2.321 & 193 & 0.021 \\
Rainfall 2018 & Rainfall 2020 & -0.478 & 171 & 0.633 \\
\hline
\end{tabular}
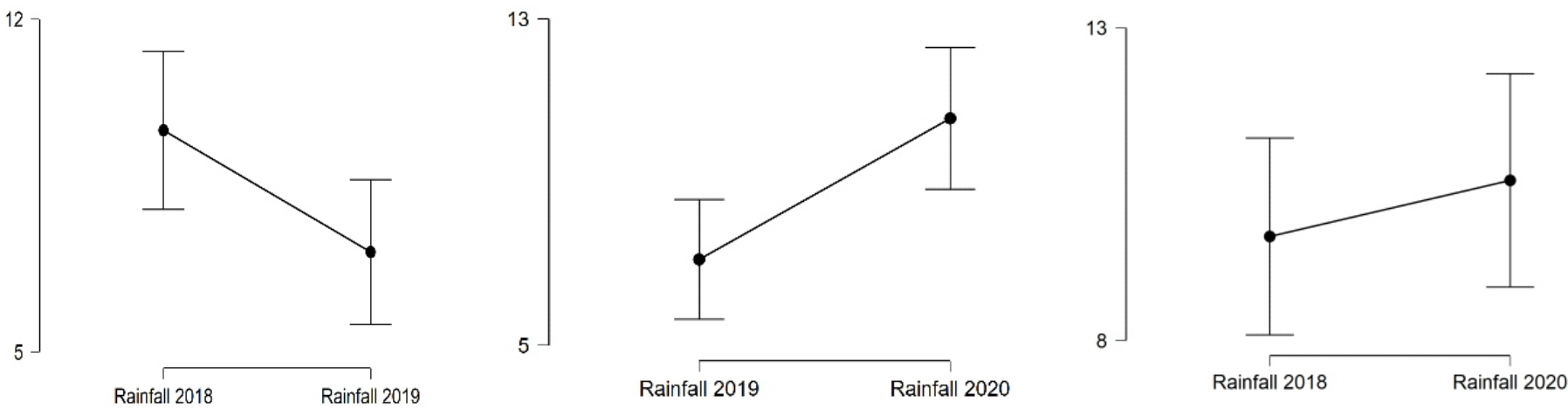

Figure 7 Comparison of mean daily rainfall at Ogan Komering Ilir Regency from 2018-2020. 


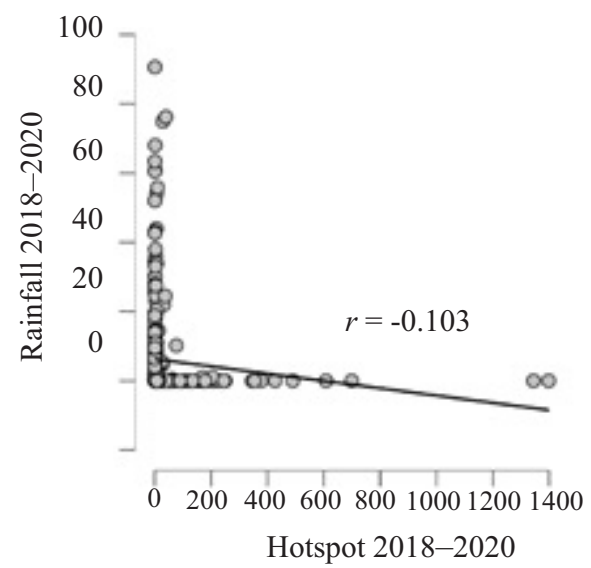

Figure 8 Correlation between hotspot and rainfall from 2018-2020 in OKI Regency.

\section{Conclusion}

This study indicates a significant decrease in the number of hotspots between before and during the COVID-19 period at the study site. We believe that the large-scale social restrictions have suppressed land burning activities. This study also verified that daily rainfall has a weak correlation with the number of hotspots. Therefore, this study shows that rainfall contributes weakly to the OKI Regency's land fires compared to human factors.

\section{Recommendation}

Field observation and hotspot ground checking are necessary for strengthening the research results.

\section{Acknowledgment}

The authors are grateful to the Laboratory of Forest and Land Fires, Department of Silviculture, Faculty of Forestry and Environment, IPB University, for supporting this research, and also to Mr. Priyanto, S.Hut., M.Si., for the profound advice on data analyses.

\section{References}

Afifuddin, Purwandani, A., Ardiyanto, R., Sumargana, L., \& Frederik, M. C. G. (2019). Is land and forest fire in Ogan Komering Ilir, Southern Sumatera, affected by climate change?. IEEE Asia-Pacific Conference on Geoscience, Electronics and Remote Sensing Technology (AGERS), 2019, 95-98, https://doi.org/10.1109/AGERS48446. 2019.9034289

Aldrian, E., \& Susanto, R. D. (2003). Identification of three dominant rainfall region within Indonesia and their relationship to sea surface temperarure. International Journal of Climatology, 23, 1435-1452. https://doi.org/ $10.1002 /$ joc. 950

Ardiansyah, M., Boer, R., \& Situmorang, A. P. (2017). Typology of land and forest fire in South Sumatera, Indonesia based on assessment of MODIS data. IOP Conference Series: Earth and Environmental Science,
54(1), 012058. https://doi.org/10.1088/1755-1315/54/1/ 012058

Armanto, M. E., Damiri, N., \& Putranto, D. D. A. (2018). Performance of fire risk estimates based on soil moisture of selected peat land use. E3S Web of Conferences, 68 , 04018. https://doi.org/10.1051/e3aconf/20186804018

Asteriniah, F., \& Sutina. (2017). Implementasi kebijakan pengendalian kebakaran hutan dan lahan gambut di Ogan Komering Ilir. Jurnal Abdimas Mandiri, 1(2), 71-77. https://doi.org/10.36982/jam.vIi2.338

[BBSDLP] Balai Besar Sumber Daya Lahan Pertanian. (2011). Peta lahan gambut Indonesia skala 1:250.000. Bogor: Badan Penelitian dan Pengembangan Pertanian.

Dennis, R. A., Mayer, J., Applegate, G., Chokkalingam, U., Colfer, C. J. P., Kurniawan, I., ..., \& Stolle, F. (2005). Fire, people and pixels: Linking social science and remote sensing to understand underlying causes and impacts of fires in Indonesia. Human Ecology, 33(4), 465504. https://doi.org/10.1007/s10745-005-5156-z

Fujii, Y., Iriana, W., Oda, M., Puriwigati, A., Tohno, S., Lestari, P., ..., \& Huboyo, H. S. (2014). Characteristics of carbonaceous aerosols emitted from peatland fire in Riau, Sumatera, Indonesia. Atmospheric Environment, 87, 164-169. https://doi.org/10.1016/j.atmosenv. 2014.01 .037

Hendrawan, I. G., Asai, K., Triwahyuni, A., \& Lestari, D. V. (2019). The interanual rainfall variability in Indonesia corresponding to El Niño Southern Oscillation and Indian Ocean Dipole. Acta Oceanologica Sinica, 38, 57-66. https://doi.org/10.1007/s13131-019-1457-1

Heriyanto, E., Syaufina, L., \& Sobri, M. (2015). Forecasting simulation of smoke dispersion from forest and land fires in Indonesia. Procedia Environmental Sciences, 24, 111-119. https://doi.org/10.1016/j.proenv.2015.03.015

Indratmoko, S., \& Rizqihandari, N. (2019). Burn area detection using Landsat 8 OLI TIRS. IOP Conference Series: Earth and Environmental Science, 338, 012035. https://doi.org/10.1088/1755-1315/338/1/012035.

Jayarathne, T., Stockwell, C. E., Gilbert, A. A., Daugherty, K., Cochrane, M. A., Ryan, K. C., ..., \& Yokelson, R. J. (2018). Chemical characterization of fine particulate matter emitted by peat fires in Central Kalimantan, Indonesia, during the 2015 El Niño. Atmospheric Chemistry and Physics, 18(4), 2585-2600. https://doi.org/10.5194/acp-18-2585-2018

Kiely, L., Spracklen, D. V., Wiedinmyer, C., Conibear, L., Reddington, C. L., Archer-Nicholls, S., ..., \& Latif, M. T. (2019). New estimate of particulate emissions from Indonesian peat fires in 2015. Atmospheric Chemistry and Physics, 19(17), 11105-11121. https://doi.org/ 10.5194/acp-19-11105-2019 
Kiely, L., Spracklen, D. V., Wiedinmyer, C., Conibear, L., Reddington, C. L., Arnold, S. R., ..., \& Adrianto, H. A. (2020). Air quality and health impacts of vegetation and peat fires in Equatorial Asia during 2004-2015. Environmental Research Letters, 15(9), 094054. https://doi.org/10.1088/1748-9326/ab9a6c

Kirana, A. P., Sitanggang, I. S., \& Syaufina, L. (2015). Poisson clustering process on hotspot in peatland area in Sumatera. Telkomnika, 13(4), 1376. https://doi.org/ 10.12928/TELKOMNIKA.v13i4.2272

Meiriza, A., Malik, R. F., \& Nurmaini, S. (2017). Spatiotemporal analysis of south sumatera hotspot distribution. International Conference on Electrical Engineering and Computer Science (ICECOS), 2017, 198-201. https://doi.org/10.1109/ICECOS.2017.8167133

Nainggolan, H. A., Veanti, D. P. O., \& Akbar, D. (2020). Utilization of NASA-GFWED and FIRMS satellite data in determining the probability of hotspots using the fire weather index (FWI) in Ogan Komering Ilir Regency, South Sumatera. International Journal of Remote Sensing and Earth Sciences (IJReSES), 17(1), 85-98. https://doi.org/10.30536/j.ijreses.2020.v17.a3202

Novitasari, N., Sujono, J., Harto, S., Maas, A., \& Jayadi, R. (2019). Drought index for peatland wildfire management in Central Kalimantan, Indonesia during El Niño phenomenon. Journal of Disaster Research, 14(7), 939-948. https://doi.org/10.20965/jdr.2019.p0939

Nurdiana, A., \& Risdiyanto, I. (2015). Indicator determination of forest and land fires vulnerability using Landsat-5 TM data (Case study: Jambi Province). Procedia Environmental Sciences, 24, 141-151. https://doi.org/10.1016/j.proenv.2015.03.019

Nurdiati, S., Sopaheluwakan, A., Agustina, A., \& Septiawan, P. (2019). Multivariate analysis on Indonesian forest fire using combined empirical orthogonal function and covariance matrices. IOP Conference Series: Earth and Environmental Science, 299(1), 012048. https:doi.org/ $10.1088 / 1755-1315 / 299 / 1 / 012048$

Nurhalimah, S. (2020). Covid-19 dan hak masyarakat atas kesehatan. SALAM Jurnal Sosial \& Budaya Syar'i, 7(6), 543-554. https://doi.org./10.15408/sjsbs.v7i6.15324

Nurhayati, A. D., Saharjo, B. H., Sundawati, L., Syartinillia, \& Vetrita, Y. (2020). Behaviour and perception of community on peat fire in Ogan Komering Ilir, South Sumatera Province. Jurnal Pengelolaan Sumberdaya Alam dan Lingkungan, 10(4), 568-583. https://doi.org/ 10.29244/jpsl.10.4.568-583

Pasaribu, S. M., \& Friyatno, S. (2012). Memahami penyebab kebakaran hutan dan lahan serta upaya penanggulangannya: Kasus di Provinsi Kalimantan Barat. SOCA: Jurnal Sosial Ekonomi Pertanian, [S.1.], 123.
Prasasti, I., Boer, R., Ardiansyah, M., Buono, A., Syaufina, L., \& Vetrita, Y. (2012). Analisis hubungan kode-kode SPBK (Sistem Peringkat Bahaya Kebakaran) dan hotspot dengan kebakaran hutan dan lahan di Kalimantan Tengah. Jurnal Pengelolaan Sumberdaya Alam dan Lingkungan, 2(2), 101. https://doi.org/10.29244/ jpsl.2.2.101

Prayoga, M. B. R., \& Yananto, A. (2017). Analisis korelasi kerapatan titik api dengan curah hujan di Pulau Sumatera dan Kalimantan. Jurnal Sains \& Teknologi Modifikasi Cuaca, 18(1), 17-24. https://doi.org/10.29122/jstmc. v18i1.2037

Putra, E. I. (2011). The effect of the precipitation pattern of the dry season on peat fire occurrence in the Mega Rice Project area, Central Kalimantan, Indonesia. Tropics, 19(4), 145-156. https://doi.org/10.3759/tropics.19.145

Riedel, S., Hobden, J. A., Miller, S., Morse, S. A., Mietzner, T. A., Detrick, B., ..., \& Mejia, R. (Eds.). (2019). Jawetz, Melnick, \& Adelberg's medical microbiology (28th ed.). McGraw Hill. https://accessmedicine.mhmedical.com/ content.aspx? bookid $=2629 \&$ sectionid $=217768734$

Rosanti, D. (2014). Potensi hutan rawa gambut sebagai sylvofishery. Sainmatika, 11(2), 818. https://doi.org/ 10.31851/sainmatika.v11i2.425

Sitanggang, I. S., Roseli, S., \& Syaufina, L. (2018). Spatial co-location patterns on weather and forest fire data. International Journal of Information Technology and Computer Science (IJITCS), 10(9), 13-20. https://doi.org/10.5815/ijitcs.2018.09.02

Syaufina, L. (2008). Kebakaran hutan dan lahan di Indonesia: Perilaku api, penyebab, dan dampak kebakaran. Malang: Bayumedia.

Syaufina, L. (2018). Forest and land fires in Indonesia: Assessment and mitigation. In P. Saumi, D. Kim, \& C. Ghosh (Eds.), Integrating disaster science and management: Global case studies in mitigation and recovery (pp. 109-121). Elsevier. https://doi.org/1 0.1016/B978-0-12-812056-9.00008-7

Syaufina, L., Nuruddin, A. A, Basharuddin, J., See, L. F., \& Yusof, M. R. M. (2004). The effects of climatic variations on peat swamp forest conditions and peat combustibility. Jurnal Manajemen Hutan Tropika, 10(2), 1-14.

Syaufina, L, \& Sitanggang, I. S. (2018). Peatland fire detection using spatio-temporal data mining analysis in Kalimantan, Indonesia. Journal of Tropical Forest Science, 30(2), 154-162. http://www.jstor.org/stable/ 26409964

Sze, J. S., Jefferson, \& Lee, J. S. H. (2019). Evaluating the social and environmental factors behind the 2015 extreme fire event in Sumatera, Indonesia. 
Environmental Research Letters, 14(1), 015001. https://doi.org/10.1088/1748-9326/aaee1d

Usman, M., Sitanggang, I. S., \& Syaufina, L. (2015). Hotspot distribution analyses based on peat characteristics using density-based spatial clustering. Procedia Environmental Sciences, 24, 132-140. https://doi.org/10.1016/j.proenv. 2015.03.018

Usup, A., Hashimoto, Y., Takahashi, H., Hayasaka, H. (2004). Combustion and thermal characteristics of peat fire in tropical peatland in Central Kalimantan, Indonesia. Tropics, 14(1), 1-19. https://doi.org/10.3759/tropics. 14.1

Waluyo, E. A., Ulya, N. A., Nurlia, A., Martin, E., \& Rahmat, M. (2020). Community adaptation to the "zero burnings" policy on peatlands: Cases in Rengas Merah-Riding and Senasih Mulya-Kayu Labu, Ogan Komering Ilir District,
South Sumatera Province. IOP Conference Series: Earth and Environmental Science, 533, 012009. https://doi.org/ $10.1088 / 1755-1315 / 533 / 1 / 012009$

Wijaya, P. T., Sitanggang, I. S., \& Syaufina, L. (2016). Density based clustering of hotspots in peatland with road and river as physical obstacles. Indonesian Journal of Electrical Engineering and Computer Science, 3(3), 714-720. https://doi.org/10.11591/ijeecs.v3.i2.pp714720

Zulfah, A. A., Howitzerni, R. C., Abdurrahim, A. Y., Ramli, M., \& Rahiem, M. D. H. (2020). Rural livelihood strategies in Sumatra after the implementation of ASEAN 2020 haze free policy' (Case study: Lebung Gajah Community, Ogan Komering Ilir, South Sumatera). IOP Conference Series: Earth and Environmental Science, 572, 012047. https://doi.org/10.1088/1755-1315/572/ $1 / 012047$ 